\title{
Synthesis of Some New Fluorine Substituted Thiobarbituricacid Derivatives as Anti HIV1 and Cyclin-Dependent Kinase 2 (CDK2) for Celltumer Division-Part II
}

\author{
Abdulrahman S. Al-Harbi*, Reda M. Abdel-Rahman, Abdullah M. Asiri \\ Department of Chemistry, Faculty of Science, King Abdul Aziz University, Jeddah, KSA \\ Email: " magiceyes2002@hotmail.com
}

Received 20 April 2014; revised 2 June 2014; accepted 19 June 2014

Copyright @ 2014 by authors and Scientific Research Publishing Inc.

This work is licensed under the Creative Commons Attribution International License (CC BY).

http://creativecommons.org/licenses/by/4.0/

\section{c) (i) Open Access}

\begin{abstract}
In search for new potential inhibitors some new fluorine substituted thiobarbituric acid derivatives $(2-4,7,8)$ and their fused/isolated heterobicyclic nitrogen systems $(5,6,9,10,11,12)$ have been synthesized from heterocyclization of fluorinated 1,3-diketoamine (1) with $\mathrm{CS}_{2}$ followed by ring closure reactions with primary nitrogen reagents. Structures of the targets have been established from elemental analysis and spectral data. Some synthesized systems have been evaluated as anti-HIV-1 and of cyclin-dependent kinase 2 (CDK2) for cell tumor division.
\end{abstract}

\section{Keywords}

Fluorinated Thiobarbituric, Heterobicyclic, Potential Inhibitors

\section{Introduction}

1,3-Diketoamine structural analogues have attracted special interest by virtue of their varied and pharmaceutically useful biological actions as anticonvulsant [1], antianaesthetic [2], anti HIV agents [3]. Also, thiobarbituric acids are used to measure the autoxidation of brain homogenates for various animals [4], treate non-alcoholic fatty liver disease [5], and determine formaldehyde and acetaldehyde in the food [6] as well as they form a type of bioactive complex with triphenyltin (IV) [7]. The introduction of fluorine atoms to heterocyclic systems often improves their biological properties, due to the stability of C-F formed [8]-[10]. Based on these facts, the

*Corresponding author.

How to cite this paper: Al-Harbi, A.S., Abdel-Rahman, R.M. and Asiri, A.M. (2014) Synthesis of Some New Fluorine Substituted Thiobarbituricacid Derivatives as Anti HIV1 and Cyclin-Dependent Kinase 2 (CDK2) for Celltumer Division-Part II. International Journal of Organic Chemistry, 4, 142-153. http://dx.doi.org/10.4236/ijoc.2014.42016 
present work deals with synthetic strategy of some new fluorinated 1,3-diketoamine for building a type of fluorinated thiobarbituric acid derivatives and their fused/isolated heterobicyclic system as anti-HIV agent.

\section{Experimental}

Melting points were determined with an electrothermal Bibly Stuart Scientific melting point sample (UK). A Perkins Elmer Model RXI-FT IR system 55529 was used for recording IR spectra of the prepared compounds. A Brucker advance DPX $400 \mathrm{MHz}$ model using TMS as internal standard was used for recording the ${ }^{1} \mathrm{H}$ and ${ }^{13} \mathrm{C}$ NMR spectra of the compounds on deuterated $\mathrm{CDCl}_{3}$. A GC-MS-GP 1000 Ex model was used for recording the mass spectra of the compounds. Electronic spectra were recorded in ethanol on Shimadzu UV and visible 310 IPC Spectro-photometer. Microanalysis was performed by the microanalytical Center of Cairo University, Egypt. Hexafluorobenzene was used as external standard for ${ }^{19} \mathrm{~F}$ NMR at $8425 \mathrm{MHz}$ (Chemical shift in $\delta$, ppm).

\section{1,3-Di(4'-fluorophenylamino)-propandione (1)}

A mixture of 4-fluoroaniline $(0.002 \mathrm{~mol})$ added to preheated diethyl malonate $(0.001 \mathrm{~mol})$ then warmed for $10 \mathrm{~min}$ and cooled. The solid thus obtained washed with ether then crystallized from THF to give $\mathbf{1}$ as greenish crystals. Yield $78 \%$, m.p. $190^{\circ} \mathrm{C}-191^{\circ} \mathrm{C}$. Analytical data; Found: C, 61.85; H, 4.01; N, 9.35; F, 13.00\%. Calculated for $\mathrm{C}_{15} \mathrm{H}_{12} \mathrm{~N}_{2} \mathrm{~F}_{2} \mathrm{O}_{2}$ (290) C, 62.06; H, 4.13; N, 9.65; F, 13.10\%. IR (DMF) $v \mathrm{~cm}^{-1}$ : $3542(\mathrm{OH}), 3180(\mathrm{NH})$, 2880 (str. $\mathrm{CH}_{2}$ ), 1650 (NHCO), 1255 (C-F), 820 (aryl CH). ${ }^{1} \mathrm{H}$ NMR $\left(\mathrm{CD}_{3} \mathrm{Cl}\right) \delta: 10.25$ (s, 1H, OH), 7.60 - 7.581, 7.53 - 6.98 (each s, 8H, aromatic protons) 2.60 - $2.58\left(\mathrm{~s}, 2 \mathrm{H}, \mathrm{CH}_{2}\right),{ }^{13} \mathrm{C} \mathrm{NMR}\left(\mathrm{CDCl}_{3}\right) \delta: 165.71,159.82,134.34$, 134.32, 121.77, 121.72, 121.68, 115.35, 115.20, 77.81, 77.59, 75.38, 66.90, 61.32, 44.39, 43.33, 40.44 - 39.49, 14.08.

\section{1,3-Di(4'-fluorophenyl)thiobarbituric acid (2)}

A mixture of $1(0.001 \mathrm{~mol})$ and $\mathrm{CS}_{2}(0.0015 \mathrm{~mol})$ inethanolic $\mathrm{KOH}(25 \mathrm{ml}, 5 \%)$ warmed for $2 \mathrm{~h}$, then poured onto ice-cooled $\mathrm{HCl}$. The solid produced filtered off and crystallized from dioxan to give $\mathbf{2}$ as yellowish crystals. Yield 68\%, m.p. $152^{\circ} \mathrm{C}-154^{\circ} \mathrm{C}$. Analytical data; Found: C, 57.53; H, 2.88; N, 8.21; S, 9.33; F, $11.24 \%$. Calculated for $\mathrm{C}_{16} \mathrm{H}_{10} \mathrm{~N}_{2} \mathrm{SF}_{2} \mathrm{O}_{2}$ (332) C, 57.83; H, 3.01; N, 8.43; S, 9.63; F, 11.44\%. UV (EtOH) $\lambda_{\max }(\epsilon): 240(0.496)$ nm. IR (DMF) $v \mathrm{~cm}^{-1}$ : $3538(\mathrm{OH}), 1660(\mathrm{C}=\mathrm{O}), 1480$ (deform. $\left.\mathrm{CH}_{2}\right), 1385$ (NCSN), 1255 (C-F), 1210 (C=S), and $678(\mathrm{C}-\mathrm{F}) .{ }^{1} \mathrm{H}$ NMR $\left(\mathrm{CD}_{3} \mathrm{Cl}\right) \delta: 10.04(\mathrm{~s}, 1 \mathrm{H}, \mathrm{OH}), 7.60$ - 7.44, 7.06 - 6.98 (each m, 8H, aromatic protons) 3.52, 2.59 - $2.58\left(\mathrm{~s}, 2 \mathrm{H}, \mathrm{CH}_{2}\right) .{ }^{13} \mathrm{C}$ NMR $\left(\mathrm{CDCl}_{3}\right) \delta: 181.15,165.72,161.00,159.38,138.22,134.85,134.32$, 126.91, 126.85, 121.74, 121.69, 115.45, 115.21, 77.79, 77.57, 77.36, 44.36, 40.43 - 39.48.

\section{1,3-Di(4'-fluorophenyl)-5-trifluoroacetyl-thiobarbituric acid (3)}

A mixture of $2(0.001 \mathrm{~mol})$ and trifluoroacetic anhydride $(0.001 \mathrm{~mol})$ with trifluoroacetic acid $(10 \mathrm{~m})$ refluxed for $2 \mathrm{~h}$, then cooled and poured onto ice cooled ethanol. The solid produced filtered off and crystallized from THF to give 3 as deep brown crystals. Yield $55 \%$ m.p. $83^{\circ} \mathrm{C}-85^{\circ} \mathrm{C}$. Analytical data; Found: C, 50.35; H, 1.88; N, 6.41; S, 7.39; F, 22.01\%. Calculated for $\mathrm{C}_{18} \mathrm{H}_{9} \mathrm{~N}_{2} \mathrm{SF}_{5} \mathrm{O}_{3}$ (428) C, 50.46; H, 2.10; N, 6.54; S, 7.47; F, $22.9 \%$. IR (DMF) $v \mathrm{~cm}^{-1}$ : $3489(\mathrm{OH}), 1688,1660$ (C=O), 1386 (NCSN), 1255 (C-F), 1182 (C=S), 880, 838 (aryl CH). M/S (M-19) (372, 100).

\section{1,3-Di(4'-fluorophenyl)-5-(4'-fluorobenzoyl)-thiobarbituric acid (4)}

A mixture of $2(0.001 \mathrm{~mol})$ and 4-fluorobenzoyl chloride $(0.001 \mathrm{~mol})$ in DMF $(10 \mathrm{ml})$ refluxed for $1 \mathrm{~h}$, cooled then poured onto ice. The solid produced filtered off and crystallized from dioxan to give $\mathbf{4}$ as brown crystals. Yield 65\% m.p. $102^{\circ} \mathrm{C}-104^{\circ} \mathrm{C}$. Analytical data; Found: C, 60.39; H, .2.66; N, 6.01; S, 6.88; F, $12.33 \%$. Calculated for $\mathrm{C}_{23} \mathrm{H}_{13} \mathrm{~N}_{2} \mathrm{SF}_{3} \mathrm{O}_{3}$ (454) C, 60.79; H, 2.86; N, 6.16; S, 7.04; F, 12.55\%. IR (DMF) $v \mathrm{~cm}^{-1}: 3487(\mathrm{OH})$, 1688, 1660 (C=O), 1386 (NCSN), 1255 (C-F), $1310(\mathrm{C}=\mathrm{S}), 838,810$ (aryl CH), 687 (C-F). ${ }^{1} \mathrm{H}$ NMR $\left(\mathrm{CDCl}_{3}\right) \delta$ : $9.71(\mathrm{~s}, 1 \mathrm{H}, \mathrm{OH}), 8.71,\left(\mathrm{~s}, 1 \mathrm{H}, \mathrm{CHCOCF}_{3}\right), 7.75-7.16,7.15-7.07$ (each m, $12 \mathrm{H}$, aromatic protons). ${ }^{13} \mathrm{C}$ NMR $\left(\mathrm{CDCl}_{3}\right) \delta: 172.04,167.45,165.17,164.19,134.90,134.88,132.26,132.20,131.84,130.47,130.211,29.54$, 129.48, 127.23, 127.22, 122.54, 122.49, 116.76, 115.95, 115.81, 115.47, 115.32, 115.17, 115.14, 77.64, 77.42, 77.21, 40.4 - 39.51. M/S: 412 (M-44, 85\%).

5-Trifluoromethyl-1,3-di-(4'-fluorophenyl)-2,7-dithioxo-3H-pyrimido[4,5-d]pyrimidin-4'-one (5); 1,3,5tri-(4'-fluorophenyl)-2,7-dithioxo-pyrimido[4,5-d]pyrimidin-4-one (6)

A mixture of compound 3 or $4(0.001 \mathrm{~mol})$ and thiourea $(0.001 \mathrm{~mol})$ in ethanol $(20 \mathrm{ml})$ with a few drops of piperidine refluxed for $4 \mathrm{~h}$, cooled and poured onto ice-acetic acid. The solid thus obtained filtered off and crystallized from ethanol to give $\mathbf{5}$ and/or $\mathbf{6}$ as brown crystals.

5: Yield $72 \%$ m.p. $193^{\circ} \mathrm{C}-195^{\circ} \mathrm{C}$. Analytical data; Found: C, 48.35; H, 1.81; N, 11.69; S, 13.55; F, $20.00 \%$. 
Calculated for $\mathrm{C}_{19} \mathrm{H}_{9} \mathrm{~N}_{4} \mathrm{~S}_{2} \mathrm{~F}_{5} \mathrm{O}$ (468) C, 48.71; H, 1.92; N, 11.96; S, 13.67; F, 20.25\%.

$\underline{6}$ : Yield $70 \%$ m.p. $126^{\circ} \mathrm{C}-128^{\circ} \mathrm{C}$. Analytical data; Found: C, 58.00; H, 2.35; N, 11.01; S, 12.55; F, $11.23 \%$. Calculated for $\mathrm{C}_{24} \mathrm{H}_{13} \mathrm{~N}_{4} \mathrm{~S}_{2} \mathrm{~F}_{3}$ (561) C, 58.29; H, 2.63; N, 11.33; S, 12.95; F, $11.53 \%$.

6: IR (DMF) $\vee \mathrm{cm}^{-1}$ : $3130(\mathrm{NH}), 1710(\mathrm{C}=\mathrm{O}), 1210(\mathrm{C}=\mathrm{S}), 1255,685(\mathrm{C}-\mathrm{F}),(\mathrm{NCSN}), 1255$ (C-F), 1580 $(\mathrm{C}=\mathrm{N}) .{ }^{1} \mathrm{H} \mathrm{NMR}\left(\mathrm{CD}_{3} \mathrm{Cl}\right) \delta: 9.55(\mathrm{~s}, 1 \mathrm{H}, \mathrm{NH}), 7.8$ - 7.6, 7.3 - 6.9 (each m, aromatic protons). ${ }^{13} \mathrm{C} \mathrm{NMR}\left(\mathrm{CD}{ }_{3} \mathrm{Cl}\right)$ $\delta: 181.1,171.8,166.35,130$ - 127.54, 122.54 - 122.11. M/S: $\mathrm{M}^{+}$(Int.), 563 (M 12.15\%), 95 (100).

1,2-Di[1',3'-di(4"-fluorophenyl)-thiobarbituric acid-5-yl] ethane (7)

A mixture of compound $2(0.002 \mathrm{~mol})$ and 1,2-dichloroethane $(0.001 \mathrm{~mol})$ in pyridine $(20 \mathrm{ml})$ refluxed for $1 \mathrm{~h}$, cooled, then poured onto ice cooled-HCl and extraction with diethyl ether and evaporated on water-bath. The solid obtained crystallized from dioxan to give 7 as yellowish crystals. Yield 55\% m.p. $142^{\circ} \mathrm{C}-144^{\circ} \mathrm{C}$. Analytical data; Found: C, 58.88; H, 3.00; N, 7.87; S, 9.11; F, 10.78\%. Calculated for $\mathrm{C}_{34} \mathrm{H}_{22} \mathrm{~N}_{4} \mathrm{~S}_{2} \mathrm{~F}_{4} \mathrm{O}_{4}(690) \mathrm{C}$, 59.12; H, 3.18; N, 8.11; S, 9.27; F, 10.01\%. UV (EtOH) $\lambda_{\max }(\epsilon): 251$ (1.0249) nm. IR (DMF) $v \mathrm{~cm}^{-1}: 3545$ (OH), 2880 (str. CH2), 1662 (C=O), 1255 (C-F), 1188 (C=S), 885 (aryl CH), $683(\mathrm{C}-\mathrm{F})$.

1,3-Di(4'-fluorophenyl)-5-arylidene-thiobarbituric acid (8)

Equimolar amounts of 2 and thiophene-2-carboxaldehyde $(0.001 \mathrm{~mol})$ in absolute ethanol $(25 \mathrm{ml}) \mathrm{with}$ a few drops of piperidine refluxed for $6 \mathrm{~h}$, cooled then concentration. The solid produced filtered off and crystallized from ethanol to give 8 as orange crystals. Yield $70 \%$ m.p. $138^{\circ} \mathrm{C}-140^{\circ} \mathrm{C}$. Analytical data; Found: C, 58.88; $\mathrm{H}$, 2.55; N, 6.41; S, 14.83; F, 8.81\%. Calculated for $\mathrm{C}_{21} \mathrm{H}_{12} \mathrm{~N}_{2} \mathrm{~S}_{2} \mathrm{~F}_{2} \mathrm{O}_{2}$ (426) C, 59.15; H, 2.81; N, 6.57; S, 15.02; F, 8.92\%. UV (EtOH) $\lambda_{\max }(\mathrm{e}): 263$ (1.026) nm. IR (DMF) $v \mathrm{~cm}^{-1}: 3010$ (aryl CH), 1680, 1662 (C=O), 1611 $(\mathrm{CH}=\mathrm{C}), 1358$ (NCSN), 1255 (C-F), $1185 \mathrm{C}=\mathrm{S}), 890,853,780$ (aryl CH), $687(\mathrm{C}-\mathrm{F}) .{ }^{1} \mathrm{H}$ NMR $\left(\mathrm{CDCl}_{3}\right) \delta: 9.23$ (s, $1 \mathrm{H}, \mathrm{CH}=\mathrm{C}$ proton), $7.6-7.56,7.42-7.44,7.05-6.98$ (each $\mathrm{m}, 11 \mathrm{H}$, thiophene and aryl protons). ${ }^{13} \mathrm{C} \mathrm{NMR}$ $\left(\mathrm{CDCl}_{3}\right) \delta: 181.10,165.67,159.36,158.15,134.40,134.38126 .84,121.85,121.67,121.62,115.37,115.32$, 115.22, 115.17, 77.88, 77.66, 77.45, 44.52, 40.43 - 39.48.

1,3-Di(4'-fluorophenyl)-5-(thiophene-2-yl)-2,7-dithioxo-8-phenylpyrimido[4,5-d]pyrimidin-4one(9a) and/ or 1,3-Di(4'-fluorophenyl)-5-(thiophene-2-yl)-2,7-dithioxo-6-phenylpyrimido[4,5-d]pyrimidin-4-one (9b)

Equimolar mixture of 8 and $\mathrm{N}$-phenyl thiourea $(0.001 \mathrm{~mol})$ in absolute ethanol $(25 \mathrm{ml})$ in a few drops of piperidine refluxed for $4 \mathrm{~h}$. the solid produced on warming isolated to give faint yellow crystals. Yield 31\% m.p. $132^{\circ} \mathrm{C}-134^{\circ} \mathrm{C}$. After cooled, another solid produced which on crystallization give a deep-yellowish crystals. Yield $26 \%$ m.p. $124^{\circ} \mathrm{C}-126^{\circ} \mathrm{C}$.

9a: analytical data; Found: C, 63.55; H, 2.88; N, 10.41; S, 11.95; F, 7.00\%. Calculated for $\mathrm{C}_{28} \mathrm{H}_{16} \mathrm{~N}_{4} \mathrm{~S}_{2} \mathrm{~F}_{2} \mathrm{O}$ (526); C, 63.87; H, 3.04; N, 10.64; S, 12.16; F, 7.22\%.

9b: analytical data; Found: C, 63.41; H, 2.81; N, 10.48; S, 11.81; F, 6.89\%. Calculated for $\mathrm{C}_{28} \mathrm{H}_{16} \mathrm{~N}_{4} \mathrm{~S}_{2} \mathrm{~F}_{2} \mathrm{O}$ (526); C, 63.87; H, 3.04; N, 10.64; S, 12.16; F, 7.22\%.

9a: UV (EtOH) $\lambda_{\max }(\epsilon): 280(0.172) \mathrm{nm}$.

9b: UV (EtOH) $\lambda_{\max }(\epsilon): 286(0.0169) \mathrm{nm} . \mathrm{IR}(\mathrm{DMF}) \vee \mathrm{cm}^{-1}: 3010$ (aryl CH), $1668(\mathrm{C}=\mathrm{O}), 1385$ (NCSN), 1256 (C-F), 1201 (C=S), 886, 838) aryl (CH), 687 (C-F).

9a: ${ }^{1} \mathrm{H}$ NMR $\left(\mathrm{CDCl}_{3}\right) \delta$ : 7.6 - 7.34, 7.29 - 7.026, 7.021 - 6.855 (each m, 17H, thiophene and aryl protons).

9a $:{ }^{13} \mathrm{C} \mathrm{NMR}\left(\mathrm{CDCl}_{3}\right) \delta:$ 181.63, 168.15, 137.76, 129.50, 124.44, 77.70, 77.48, 77.27, 40.43, 39.48.

$\underline{\underline{\mathbf{9 b}}}:{ }^{13} \mathrm{C} \mathrm{NMR}\left(\mathrm{CDCl}_{3}\right) \delta: 181.54,181.07,165.711,159.78,158.16,138.53,138.21,134.88,134.33,129.83$, 129.41, 129.13, 128.79, 126.87, 125.76, 124.99, 124.09, 122.54, 121.93, 121.87, 121.71, 121.66, 115.32, 115.24, $115.20,115.17,77.81,77.59,77.38,40.38$ - 39.43.

M/S $428\left(\mathrm{M}^{+2}, 88 \%\right), 401(100)$.

7-Amino-5-(thiophene-5-y)-1,3-di(4'-fluorophenyl)-2-thioxo-pyrimido[4,5-d]pyrimidin-4-one (10)

A mixture of $8(0.001 \mathrm{~mol})$ and guanidine bicarbonate $(0.001 \mathrm{~mol}$, in drops $\mathrm{HCl})$ in ethanol $(50 \mathrm{ml})$ with a few drops of piperidine refluxed for $4 \mathrm{~h}$, cooled then poured onto ice. The yielded solid filtered off and crystallized from ethanol to give $\mathbf{1 0}$ as yellowish crystals. Yield $66 \%$ m.p. $180^{\circ} \mathrm{C}-182^{\circ} \mathrm{C}$. Analytical data; Found: C, 56.43; H, 2.69; N, 14.81; S, 13.51; F, 7.91\%. Calculated for $\mathrm{C}_{22} \mathrm{H}_{13} \mathrm{~N}_{5} \mathrm{~S}_{2} \mathrm{~F}_{2} \mathrm{O}$ (465) C, 56.77; H, 2.79; N, 15.05; S, 13.76; F, 8.17\%. IR (DMF) $v \mathrm{~cm}^{-1}$ : 3310, $3150\left(\mathrm{NH}_{2}, \mathrm{NH}\right), 3005$ (aryl CH), $1668(\mathrm{C}=\mathrm{O}), 1620\left(\right.$ deform. $\left.\mathrm{NH}_{2}\right)$, $1590(\mathrm{C}=\mathrm{N}), 1385$ (NCSN), 1255 (C-F), 1201 (C=S), 910, 880, 785 (aryl CH), $687(\mathrm{C}-\mathrm{F}) .{ }^{1} \mathrm{H}$ NMR $\left(\mathrm{CDCl}_{3}\right) \delta$ : 4.57 (s, $\left.2 \mathrm{H}, \mathrm{NH}_{2}\right), 7.65-7.59,7.01-6.98$, (each $\mathrm{m}, 11 \mathrm{H}$, thiophene and aryl protons). ${ }^{13} \mathrm{C} \mathrm{NMR}\left(\mathrm{CDCl}_{3}\right) \delta$ : $165.65,159.63,158.02,134.52,134.31,121.59,121.54,115.26,115.11,78.06,77.84,77.63,44.77,40.31-$ 39.36, 30.83.

1,4-Di[1',3'-di(4"-fluorophenyl)-thiobarbituric acid-5-thiophene-2-methyl]piprazine (11) 
A mixture of $8(0.002 \mathrm{~mol})$ and piperazine $(0.001 \mathrm{~mol})$ in absolute ethanol $(30 \mathrm{ml})$, with few drops of piperidine refluxed for $4 \mathrm{~h}$, cooled. The solid thus obtained filtered off and crystallized from ethanol to give $\mathbf{1 1}$ as yellowish crystals. Yield $71 \%$ m.p. $138^{\circ} \mathrm{C}-140^{\circ} \mathrm{C}$. M. m.p. with 8 gave m.p. $120^{\circ} \mathrm{C}-125^{\circ} \mathrm{C}$. Analytical data; Found: C, 58.41; H, 3.25; N, 8.61; S, 13.33; F, 7.88\%. Calculated for $\mathrm{C}_{46} \mathrm{H}_{34} \mathrm{~N}_{6} \mathrm{~S}_{4} \mathrm{~F}_{4} \mathrm{O}_{4}$ (938) C, 58.84; H, 3.62; N, 8.95; S, 13.64; F, 8.10\%. UV (EtOH) $\lambda_{\max }$ (є): 256 (1.019) nm. IR (DMF) $v \mathrm{~cm}^{-1}: 3420$ (OH), 3006 (aryl CH), 2895 (aliphatic CH), 1662 (C=O), 1438 (deform. $\mathrm{CH}_{2}$ ), 1385 (NCSN), 1255 (C-F), 1201 (C=S), 864 (aryl CH), 687 (C-F). M/S: (Int.\%); 720 (M $\left.\mathrm{M}^{+2}, 25.11\right) 511$ (12.15), 427 (55.15), 108 (5.68); 95 (100), 85 (18.23), 83 (213).

\section{1,2-Di[1',3'-di(4"-fluorophenyl)-thiobarbituric acid-5-yl]bicarbonyl (12)}

To a mixture of $2(0.002 \mathrm{~mol})$ in dry $\mathrm{C}_{6} \mathrm{H}_{6}$, oxalyl dichloride $(0.001 \mathrm{~mol})$ added dropwise the added of a few drops of piperidine the warmed slowly for $20 \mathrm{~min}$. the solid obtained was filtered off and crystallized from dioxan to give 12 as yellowish crystals. Yield $88 \%$ m.p. $232^{\circ} \mathrm{C}-234^{\circ} \mathrm{C}$. Analytical data; Found: C, 56.55; H, 2.31; N, 7.60; S, 8.81; F, 10.35\%. Calculated for $\mathrm{C}_{34} \mathrm{H}_{18} \mathrm{~N}_{4} \mathrm{~S}_{2} \mathrm{~F}_{4} \mathrm{O}_{6}$ (718) C, 56.82; H, 2.80; N, 7.79; S, 8.91; F, 10.58\%. UV (EtOH) $\lambda_{\max }(\epsilon): 271(0.14912) \mathrm{nm}$. IR (DMF) $v \mathrm{~cm}^{-1}: 3010$ (aryl CH), $1785(\mathrm{C}=\mathrm{O}), 1662(\mathrm{C}=\mathrm{O}), 1384$ (NCSN), 1255 (C-F), 1155 (C=S), 864, 841, 786, 749 (aryl CH), 658 (C-F). ${ }^{1} \mathrm{H}$ NMR $\left(\mathrm{CDCl}_{3}\right) \delta: 9.18$ (s, 2H, $\mathrm{OH}), 7.43-7.23$ (m, 16H, aryl protons), 6.65 (s, 2H, $\mathrm{CH}=\mathrm{C}) .{ }^{13} \mathrm{C}$ NMR $\left(\mathrm{CDCl}_{3}\right) \delta: 181.631,168.11,166.01$, 162.13, 137.67, 129.50, 126.40, 124.44, 77.45, 77.24, 77.03, 40.49 - 39.55. M/S: (Int.\%): $362\left(\mathrm{M}^{+1}\right)$ 100\%, 317 (8), 306 (85), 306 (14), 97 (2), 98 (12).

\section{Results and Discussion}

1,3-Diketoamines obtianed from 1,3-biester with aromatic amine [11]. Similary, diethylmalonate and 4-fluoroaniline added then warmed for few min to obtain the fluorinated 1,3-diketoamine (1) (Scheme 1). Refluxing of compound 1 with $\mathrm{CS}_{2}$ in alcoholic $\mathrm{KOH}$ [12] yielded 1,3-di(4'-fluorophenyl)thiobarbituric acid (2) (Scheme 1). UV absorption spectrum of 1 recorded $\lambda_{\max }$ at $230 \mathrm{~nm}$ while that of 2 showed $\lambda_{\max }$ at $240 \mathrm{~nm}$. A higher $\lambda_{\max }$ of 2 than 1 confirm that cyclic resonated structure with both bathochromic and hypthochromic factors. IR absorption spectrum of 1 showed $v$ at 3542 \& 3180 attributed to two isolated OH \& NH functional groups while that of 2 recorded anenolic $\rightleftharpoons$ ketonic functional groups at $v 3538 \mathrm{~cm}^{-1}$ with lacks of NH bands. In addition $v 1385$, $1255,1210 \mathrm{~cm}^{-1}$ for cyclic NCSN, C-F and C=S functional groups.

${ }^{1} \mathrm{H}$ NMR spectrum of 2 exhibited a resonated signals at 2.59 and $3.52 \mathrm{ppm}$ for active $\mathrm{CH}_{2}$ coupling and enolic protons, with a signals at $\delta 7.65-6.98 \mathrm{ppm}$ for aryl protons ${ }^{13} \mathrm{C}$ NMR spectrum of 2 showed resonated signals at $\delta 165.65,159.63$, and $158.02 \mathrm{ppm} \mathrm{C}=\mathrm{S}, 2 \mathrm{C}=\mathrm{O}$ carbon and $\delta$ at 134.52, $134.51 \mathrm{ppm}$ for the C-F carbons, in addition of aromatic carbons. Mass spectrum 2 exhibited the molecular ion with a base peak at m/e 334 and 95 . Treatment of ethanolic solution of $\mathbf{2}$ with $\mathrm{FeCl}_{3}$ solution gave the deep violet colour which confirms that phenolic formula. Presence of $\alpha$-active methylene at position-5 of the thiobarbituric acid 2 , led to synthesize various fluorinated isolated and/or fused heterobicyclic nitrogen systems.

Fluorinated compound 2 underwent acylation using trifluoroacetic anhydride-trifluoroacetic acid [13] produced5-trifluoroacetyl derivatives 3, while fluorinated aroylation using 4-fluorobenzoyl chloride in warming DMF yielded 5-(4'-fluorobenzoyl) derivative 4 (Scheme 1). Structures of compounds 3 and 4 deduced from spectral measurements. A higher $\lambda_{\max }$ of $\mathbf{4}>\mathbf{3}>\mathbf{2}$ confirm that extension conjugation system was as well as adductive electronic density of $\mathrm{COCF}_{3}$ and or $\mathrm{COC}_{6} \mathrm{H}_{4} \mathrm{~F}$. IR spectrum of 4 showed absorption bands at $v 3489$ and 3304 attributed to $\mathrm{OH}$, and C=O with 1688, $1660 \mathrm{~cm}^{-1}$ cyclic NCSN in addition at $v 1255 \mathrm{~cm}^{-1}$ for C-F absorption bands. Compounds $\mathbf{3} \& \mathbf{4}$ showed the lacks of $\mathrm{CH}_{2}$. ${ }^{1} \mathrm{H}$ NMR spectrum of $\mathbf{4}$ exhibited a resonated signals at 9.71 and $8.71 \mathrm{ppm}$ for $\mathrm{OH}$ and aliphatic $\mathrm{CH}-\mathrm{COCF}_{3}$ down field, different aromatic protons at $\delta 7.75-7.166$ and $7.156-7.07$ ppm. ${ }^{13} \mathrm{C}$ NMR spectrum of 4 recorded signals at $\delta 172.04,167.45,165.17,164.19 \mathrm{ppm}$ attributed to $\mathrm{C}=\mathrm{S}$, and $\mathrm{3C}=\mathrm{O}$ carbons. In addition, $\delta 134.9,132.2 \mathrm{ppm}$ for C-F and C-N with aromatic carbons at $\delta 131.8$ $122.4 \mathrm{ppm}$. Morever M/S spectrum of 3 recorded m/z at 372 (M-19) as a base peak, while that of 4 exhibited $\mathrm{m} / \mathrm{e}$ at 417 (M-44) with a base peak at 379.

Fluorinated fused heterobicyclic nitrogen systems $\mathbf{5}$ and $\mathbf{6}$ obtained from cyclocondensation of $\mathbf{3}$ and/or $\mathbf{4}$ with 4-chlorophenyl hydrazine hydrochloride in refluxing absolute ethanol [14] furnished the fluorinated pyrimido [3,4-d]pyrimidine thiones $(\mathbf{5} \& \mathbf{6})$ respectively (Scheme 1). Structures of compounds 5 and $\mathbf{6}$ were established from correcteelemental analysis and spectral data. IR Spectrum of $\mathbf{6}$ recorded an absorption bands at $v 3130$, 1710 and $1210 \mathrm{~cm}^{-1}$ for the $\mathrm{NH}, \mathrm{C}=\mathrm{O}$ and $\mathrm{C}=\mathrm{S}$ functional groups with $v$ at 1255 for C-F with $1580 \mathrm{~cm}^{-1}$ for $\mathrm{C}=\mathrm{N}$ functional group. ${ }^{1} \mathrm{H}$ NMR spectrum of 6 showed a resonated signals at $\delta 9.55$ and $7.8-7.6 \& 7.3-6.9$ 

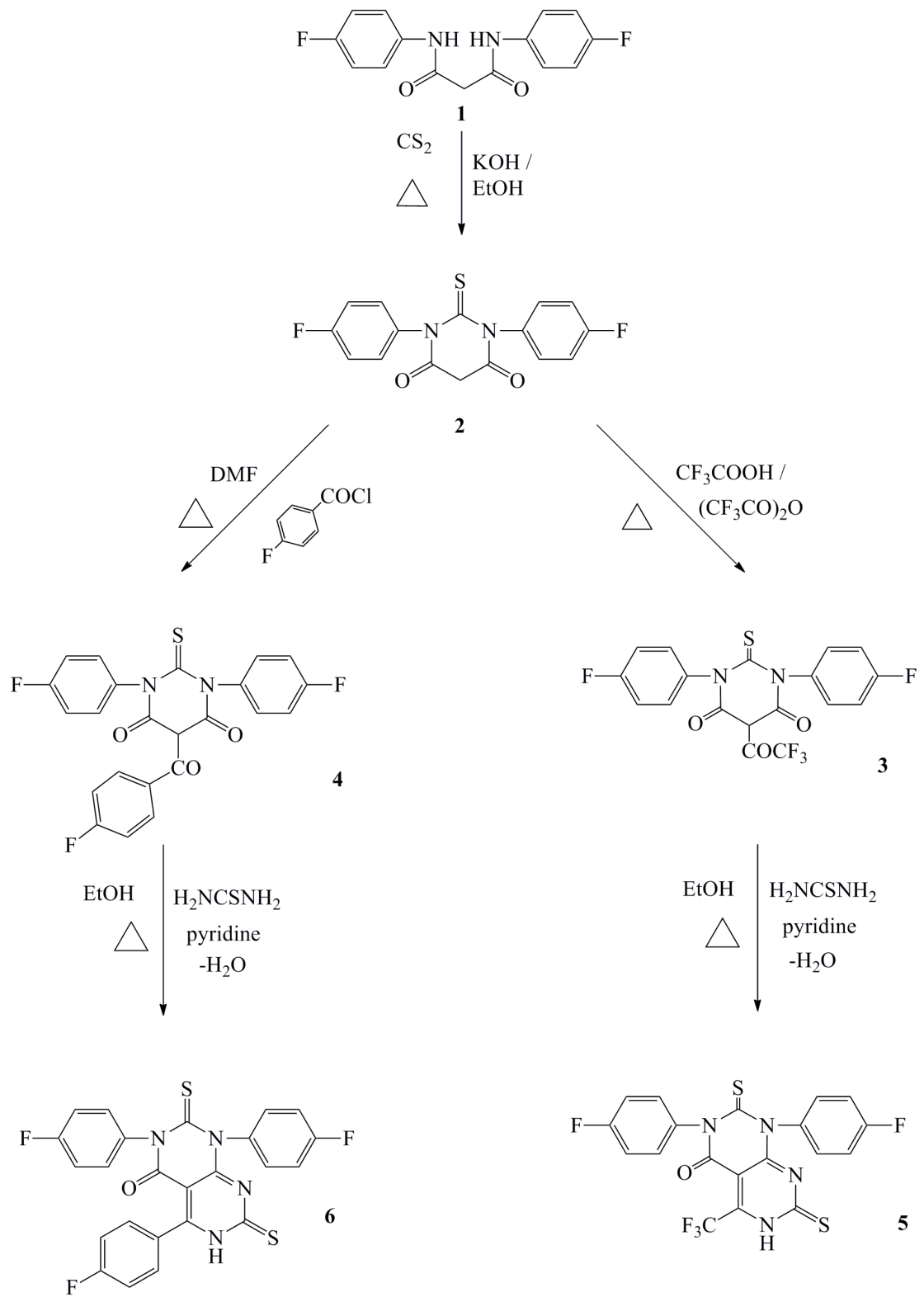

Scheme 1. Synthetic of compounds 3-6.

ppm for $\mathrm{NH}$ and aromatic protons. ${ }^{13} \mathrm{C}$ NMR spectrum of $\mathbf{6}$ exhibiteda resonated signals at $\delta$ 181.1, 171.8, 166.35 ppm for $2 \mathrm{C}=\mathrm{S}$ and $\mathrm{C}=\mathrm{O}$ carbons with aromatic carbons at $\delta 130-127.54,122.54-122.11$ ppm. Mass spectrum of 6 showed the molecular ion and a base peak at m/z $563(\mathrm{M}+2)$, 95 as 4-fluorophenyl radical. A simple alkylation for active methylene at position-5 in the compound 2 deduced from treatment with 1,2-dichloroethane (2:1 by mole) in refluxing DMF to produce 1,2-di(thiobarbituric acid-5-yl)ethane (7) (Scheme 2). Fine structure of compound 7 deduced from that elemental analysis and spectral measurements. UV absorption of 7 recorded $\lambda_{\max }$ at $251 \mathrm{~nm}$ in compare with 2 at $240 \mathrm{~nm}$. IR absorption spectrum showed an aliphatic bands at $v$ 3545, 2880, $1662 \mathrm{~cm}^{-1}$ for stretching $\mathrm{OH}, \mathrm{CH}_{2} \& \mathrm{C}=\mathrm{O}$ functional groups with $1255 \mathrm{~cm}^{-1}$ for C-F. It is interesting that condensation of compound $\mathbf{8}$ with thiophene-2-carboxaldehyde in warming ethanol with a few drops of piperidine according to Knoevenagel reaction [15] yielded 1,3-di(4'-fluorophenyl)-5-arylidene-thiobarbituric acid (8) (Scheme 2).

Cycloaddition Compound $\mathbf{8}$ with $\mathrm{N}$-phenyl thiourea in refluxing ethanol-piperidine furnished the pyrimido [4,5-d]pyrimidindithiones (9a, b) (Scheme 2). Formation of compounds $\mathbf{9}$ may be take place via cycloaddition 


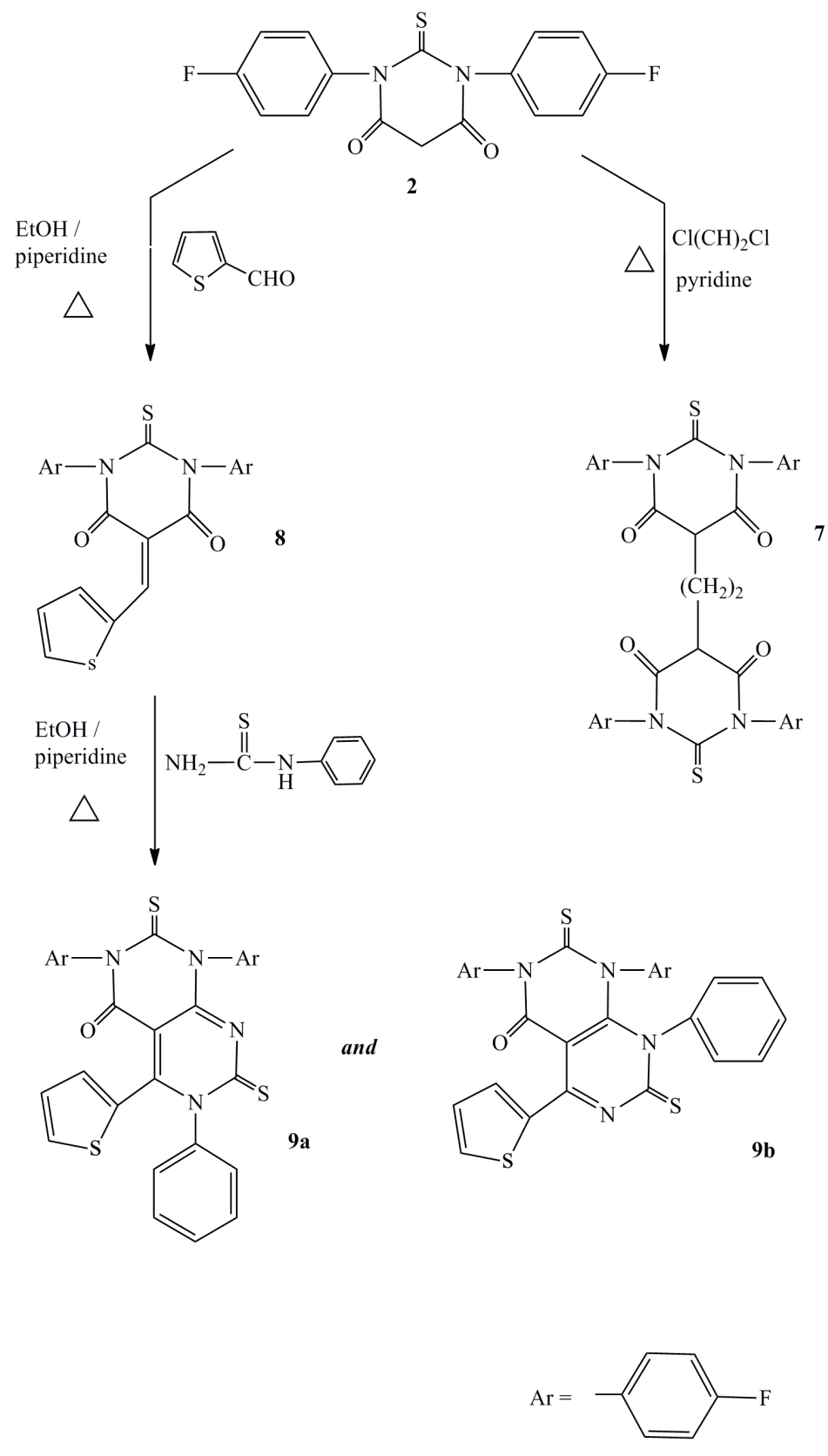

Scheme 2. Synthetic of compounds 7-9.

reaction through two possible routes (Figure 1). Structure of 8 established mainly from spectral data. UV absorption spectrum showed $\lambda_{\max }$ at $263 \mathrm{~nm}$ higher than 2 which is due to new $\alpha, \beta$-unsaturated ketonic system formed of 8 . ${ }^{1} \mathrm{H}$ NMR spectrum recorded a resonated signals at $\delta 9.23 \mathrm{ppm}$ for the arylidene proton. Also, ${ }^{13} \mathrm{C}$ NMR spectrum of exhibited a different types of carbons at $\delta 181.10,165.67,160.91,159.76,159.29,158.15$, and 134.40 - 115.17 ppm attributed to $\mathrm{C}=\mathrm{S}, \mathrm{C}=\mathrm{O}, \mathrm{C}=\mathrm{N}, \mathrm{C}-\mathrm{S}, \mathrm{C}-\mathrm{N}$ and $\mathrm{C}=\mathrm{C}$ carbons. IR spectrum recorded lacks of $\mathrm{OH}, \mathrm{NH}$ groups and $\mathrm{CH}_{2}$ with addition a new group at $1610 \mathrm{~cm}^{-1}$ for $\mathrm{CH}=\mathrm{C}$. M/S of 8 showed a molecular ion at $\mathrm{m} / \mathrm{z} 428\left(\mathrm{M}^{+2}, 88 \%\right)$, with a base peak at 401 . The higher reactivity of compound 8 towards cycloaddition with N-phenyl thiourea to electrophilic carbon at position-3 of thiobarbituric acid followed by addition reaction of $\mathrm{H}_{2}-\mathrm{N}-\mathrm{CS}$ group to electrophilic carbon arylidene at posiyion-5 to give 9a. A possible other route is a nucleophilic reaction $\mathrm{CS}-\mathrm{NH}_{2}$ group to a electrophilic carbon at position-3 of thiobarbituric acid followed by addition reaction of $\mathrm{HN}-\mathrm{Ph}$ group to electrophilic carbons of arylidene at position-5 to give 9a. 

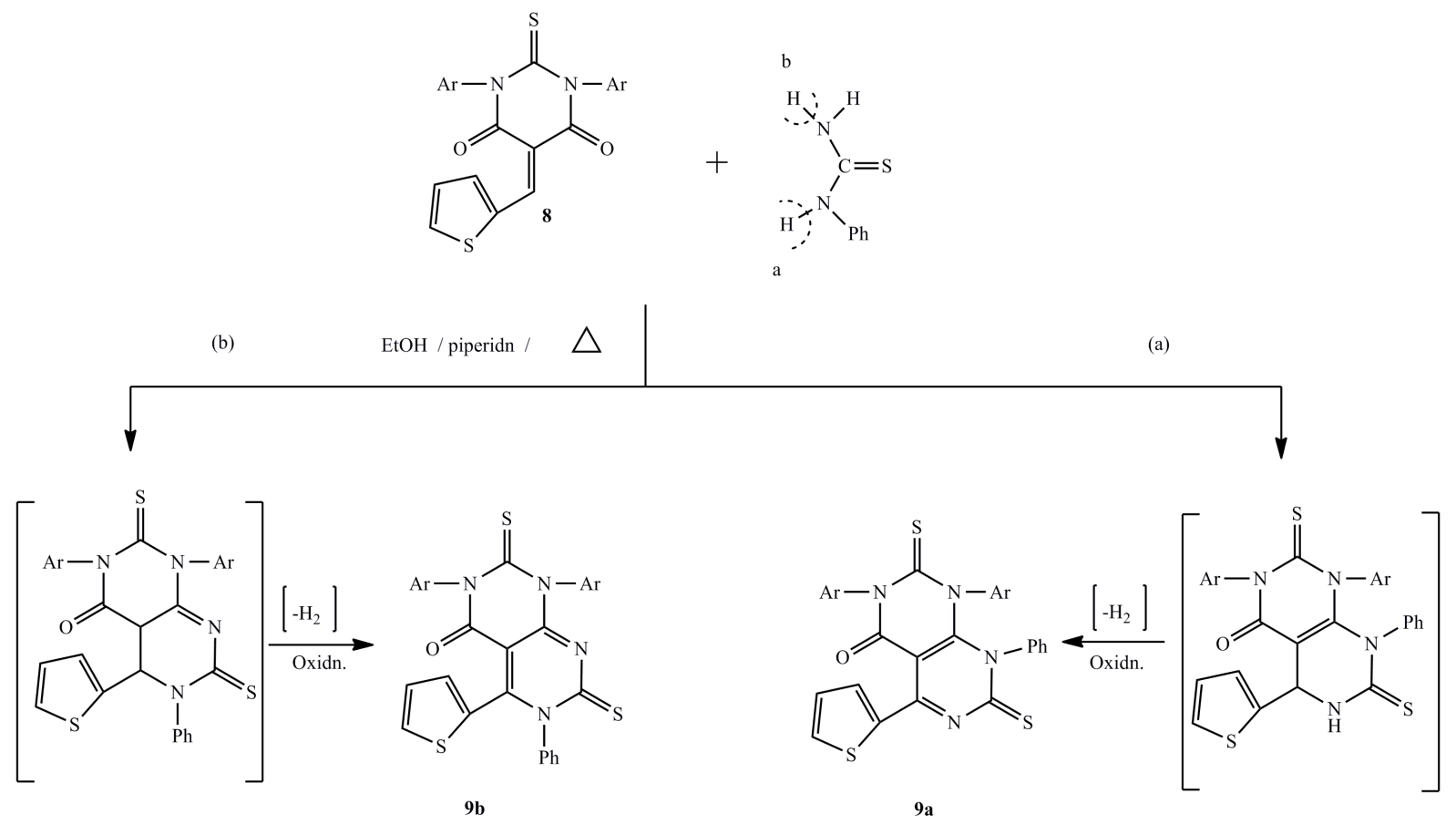

Figure 1. Possible formation of 9a and 9b from 8.

A possible other route is a nucleophilic reaction $\mathrm{CS}-\mathrm{NH}_{2}$ group to a electrophilic carbon at position-3 of thiobarbituric acid followed by addition reaction of $\mathrm{HN}-\mathrm{Ph}$ group to electrophilic carbons of arylidene at position-5 to give 9a. The kinetics and mechanism of this reaction were controlled by the highly acidic proton of $\mathrm{Ph}-\mathrm{NH}$ than $\mathrm{H}_{2} \mathrm{~N}-\mathrm{CS}$ proton (as thioamide). A higher yield of $\mathbf{9 a}$ is due to a high withdrawing of Ph group than amidic $\mathrm{CONH}_{2}$. Also, a higher melting point of $\mathbf{9 a}$ than $\mathbf{9 b}$ is due to a higher stability of $\mathbf{9 a}$ than $\mathbf{9 b}$ which characterized by a repulsion between phenyl and thiophenegroups. Thus, compounds $\mathbf{9 a}$ and $\mathbf{9 b}$ are isomeric structure. Structure of compounds $\mathbf{9 a} \& \mathbf{9 b}$ determined from: 1) UV absorption of compounds 9a recorded $\lambda_{\max }$ at $280 \mathrm{~nm}$, and that of $\mathbf{9 b}$ at $286 \mathrm{~nm}$; 2) IR absorption spectra of 9a \& 9b showed a lacks of $\mathrm{OH}$, NH functional groups and $\mathrm{CH}_{2}$; 3) ${ }^{1} \mathrm{H}$ NMR spectra of $\mathbf{9 a}$ and $\mathbf{9 b}$ recorded a resonated signals at $\delta 7.60-7.34,7.29-7.026$ and $7.021-6.855$ ppm for different thiophene and aryl protons; 4) ${ }^{13} \mathrm{C}$ NMR for compound 9a, recorded the resonated signals at $\delta$ 181.63, 168.15 ppm for $\mathrm{C}=\mathrm{S}$ and $\mathrm{C}=\mathrm{O}$ with 137.67, $129.50-124.44 \mathrm{ppm}$ for aromatic carbons, while that of $\mathbf{9 b}$ showed signals at $\delta 181.54,181.07,165.711 \mathrm{ppm}$ for $2 \mathrm{C}=\mathrm{S}$ and $\mathrm{C}=\mathrm{O}$ with other $\delta$ at 138.166, $134.33-124.99$ and 122.54 - 121.66 ppm for aromatic carbons.

Cycloaddition of compound $\mathbf{8}$ with gaunidine bicarbonate in refluxing ethanol-piperidine afforded the aminopyrimido[4,5-d]pyrimidinthione (10) (Scheme 3). Structure of compound 10 characterized by spectral data. IR absorption spectrum gave a good indication by exhibited the absorption band at $v 3350 \mathrm{~cm}^{-1}$ for $\mathrm{NH}_{2}$ group with other at $v 1620,1580 \mathrm{~cm}^{-1}$ for bending $\mathrm{NH}_{2}$ and $\mathrm{C}=\mathrm{N}$ functional groups. ${ }^{1} \mathrm{H}$ NMR spectrum showed a resonated signals at $\delta 4.57 \mathrm{ppm}$ for the $\mathrm{NH}_{2}$ protons with thiophene and aryl protons at $\delta 7.65-7.59$ and $7.01-$ $6.98 \mathrm{ppm}$ with lacks of $\mathrm{CH}=\mathrm{C}$ protons. ${ }^{13} \mathrm{C}$ NMR spectrum recorded the resonated signals of different carbons at $\delta$ 165.65, 159.63 and 158.02 ppm for $\mathrm{C}=\mathrm{S}, \mathrm{C}=\mathrm{O}$ and $\mathrm{C}=\mathrm{NH}$. The interaction between compound 8 and piperazine (2:1 by mole) in refluxing ethanol-piperidine [16]-[18] furnished 1,4-disubstituted piperazine (11) (Scheme 3). Former structure of compound 11 deduced for spectral measurements. A good characterized obtained from that UV spectrum which showed $\lambda_{\max }$ at $256 \mathrm{~nm}$ higher than that of 2 (240 nm). IR spectrum recorded a weak band at $3550 \mathrm{~cm}^{-1}$ for $\mathrm{OH}$ with 2928, $2858 \mathrm{~cm}^{-1}$ for $\mathrm{CH}, \mathrm{CH}_{2}$. In addition to $1662 \mathrm{~cm}^{-1}$ attributed to $\mathrm{C}=\mathrm{O}$, with $v$ at $1504,1438 \mathrm{~cm}^{-1}$ for deformation of $\mathrm{CH}_{2}$. Mass spectrum of $\mathbf{1 1}$ recorded the molecular ion and a base peak at $\mathrm{m} / \mathrm{e} 720(\mathrm{M}+25.11), 95(100)$. Formation of 12 was deduced from treatment of 2 with piperidine as base to produce the carbanion which attacks the first electrophilic carbon of oxalyl followed by a second attack of other nucleophiliccarbanion of thiobarbituric acid to the second electrophilic carbon of oxalyl chloride (Scheme 4). A possible tautomerism of compound $\mathbf{1 2}$ gives us a good indication about the acidic character of two protons within 

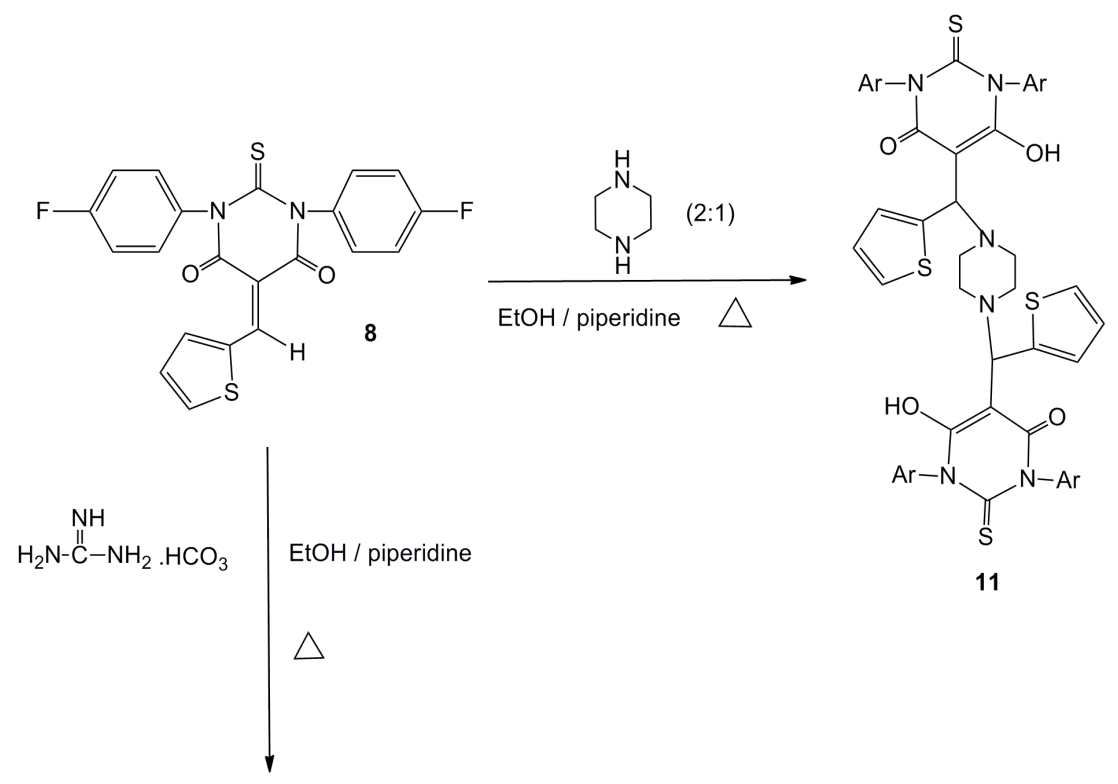

11<smiles>Nc1nc(-c2cccs2)c2c(=O)n(Cl)c(=S)n([Al])c2n1</smiles>

10

$\mathrm{Ar}=\longrightarrow \mathrm{F}$

Scheme 3. Synthetic of compounds 10 \& 11.

the former structure which facilitated the oxidation $\rightleftharpoons$ reduction process.

Finally structure of compound 12 established spectral data. UV absorption spectrum showed $\lambda_{\max }$ at $271 \mathrm{~nm}$ which is higher than starting material 2 . These highly absorption is confirmed that larger extension of heteroconjugation system bearing both bathochromic and hypsochromic moieties. IR spectrum showed a lacks of bands for $\mathrm{OH}, \mathrm{NH}$ functional groups and $\mathrm{CH}_{2}$ with the additional bands at 1785,1680 and $1662 \mathrm{~cm}^{-1}$ for $3 \mathrm{C}=\mathrm{O}$ groups. A functional groups at $v 1380,1255$ and $1210 \mathrm{~cm}^{-1}$ attributed to NCSN, C=S and C-F functional groups.

${ }^{1} \mathrm{H}$ NMR spectrum exhibited two resonated signals at $\delta 9.18 \mathrm{ppm}$ attributed to $\mathrm{OH}$ proton from the free solubility of $\mathbf{1 2}$ in sodium hydroxide solution. ${ }^{13} \mathrm{C}$ NMR spectrum of $\mathbf{1 2}$ recorded the resonated signals at $\delta 181.63$,

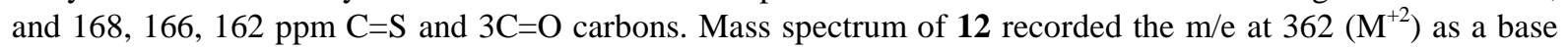
peak. Finally, synthesized single fluorine which attributed to phenyl ring in all fluorinates systems appeared in the region at $\delta-125$ to $-128 \mathrm{ppm}$.

\section{Conclusion}

Novel fluorinated thiobarbituric acid derivatives have been synthesized and then evaluated as medicinal agents, Among these compounds $\mathbf{9 a}>\mathbf{1 2}>\mathbf{2}>\mathbf{1 1}$ exhibited a higher activity as anti HIV agents, while compounds $\mathbf{1 2}>$ $\mathbf{7}>\mathbf{2}>\mathbf{3}>\mathbf{4}$ have a good activity toward enzymatic inhibition as cyclin-dependent kinase 2 (CDK2) for cell tumer division

\section{Biology}

\subsection{Anti-HIV Evaluation}

The research for a more effective and less toxic agents has brought into focus potent yet structurally different 


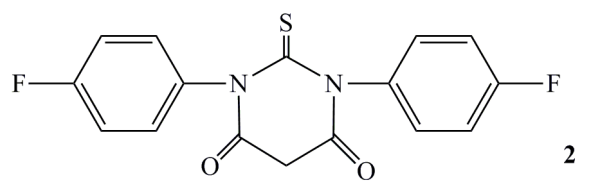

$$
\begin{array}{r|l}
\mathrm{C}_{6} \mathrm{H}_{6} / & \mathrm{Cl} \\
\text { piperidine } & \stackrel{1}{\mathrm{l}}=\mathrm{O} \\
\triangle & \mathrm{C}=\mathrm{O} \\
-2 \mathrm{HCl} & \stackrel{\mathrm{Cl}}{ }
\end{array}
$$<smiles>C=C1C(C(=O)C(=O)C2C(=O)N([Al])C(=S)N([Al])C2=O)C(=O)N([Al])C(=S)N1[Al]</smiles><smiles>O=C1C(=C(O)C(O)=C2C(=O)N([Al])C(=S)N([Al])C2=O)C(=O)N([Al])C(=S)N1[Al]</smiles>
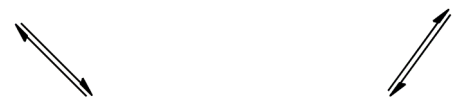<smiles>O=C(C(=O)c1c(O)n([Al])c(=S)n([Al])c1=O)c1c(O)n([Al])c(=S)n([Al])c1=O</smiles>

12

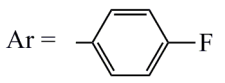

Scheme 4. Synthetic of compounds 12.

non-nucleoside HIV-1 reverse transcriptase inhibitors (NNRTIs) [19]. Abdel-Rahman [20]-[23] synthesized a pool of new fluorinate heterocyclic nitrogen systems as HIV inhibitor agents. Thus, the main aim of the present work tends to search for new fluorinated thiobarbituric acid derivatives and their related fused heterobicyclic nitrogen systems as inhibitors of HIV cases. Some of the synthesized targets have been evaluated as anti-HIV agents. The procedure used in the National Cancer Institute test for agents active against Human Immunodeficiency Virus (HIV) is designed to detect agent acting at any stage of the virus reproductive cycle. The assay basically involves the killing of $\mathrm{T}_{4}$ lymphocytes by HIV and used the tetrazoliumsalt XTT, as indicator [24]. From the results obtained in (Table 1 ) we showed that, all the fluorinated thiobarbituric acid derivatives exhibited maximum protection $<10 \%$ for the infected cell and $>50 \%$ for the uninfected cell. It is interested that, the full fluorinated thiobarbituric acids obtained exhibited maximum protection $>20 \%$ for the infected cell and $>50 \%$ for the uninfected cell. Only, the compound 9a recorded a highly percent of protection at lower dose (molar) 
Table 1. The anti-HIV-IC50 values of the fluorinated compounds.

\begin{tabular}{|c|c|c|c|c|c|}
\hline Compoud & $\mathrm{IC}_{50}(\mu \mathrm{g} \mathrm{ml})$ & Dose (molar) & Percent of protection & Percent of Infected & Control uninfected \\
\hline \multirow{2}{*}{2} & \multirow{2}{*}{$1.63 \times 10^{-4}$} & $2.00 \times 10^{-4}$ & 7.74 & 10.51 & 40.16 \\
\hline & & $6.35 \times 10^{-8}$ & 6.30 & 9.11 & 99.62 \\
\hline 3 & $6.55 \times 10^{-5}$ & $3.17 \times 10^{-8}$ & 6.68 & 9.48 & 99.74 \\
\hline 4 & $>1.60 \times 10^{-4}$ & $3.17 \times 10^{-8}$ & 5.08 & 6.98 & 98.57 \\
\hline 5 & $1.07 \times 10^{-4}$ & $2.00 \times 10^{-4}$ & 1.94 & 3.90 & 5.32 \\
\hline 6 & $>1.00 \times 10^{-4}$ & $1.00 \times 10^{-7}$ & 7.55 & 10.32 & 88.33 \\
\hline \multirow{2}{*}{7} & \multirow{2}{*}{$>100 \times 10^{-4}$} & $3.17 \times 10^{-8}$ & 4.9 & 7.75 & 44.93 \\
\hline & & $1.00 \times 10^{-4}$ & 3.33 & 9.13 & 53.27 \\
\hline \multirow{2}{*}{$9 a$} & \multirow{2}{*}{$1.05 \times 10^{-4}$} & $2.00 \times 10^{-7}$ & 12.31 & 14.94 & 86.39 \\
\hline & & $6.32 \times 10^{-5}$ & 14.84 & 13.39 & 90.04 \\
\hline \multirow{2}{*}{11} & \multirow{2}{*}{$>1.00 \times 10^{-4}$} & $3.17 \times 10^{-8}$ & 0.38 & 2.37 & 101.10 \\
\hline & & $1.00 \times 10^{-4}$ & 7.86 & 9.11 & 95.52 \\
\hline \multirow{4}{*}{12} & \multirow{4}{*}{$9.55 \times 10^{-5}$} & $2.00 \times 10^{-7}$ & 5.06 & 6.96 & 90.71 \\
\hline & & $6.33 \times 10^{-6}$ & 23.03 & 24.57 & 94.28 \\
\hline & & $2.00 \times 10^{-5}$ & 6.30 & 8.17 & 92.17 \\
\hline & & $6.32 \times 10^{-5}$ & 19.28 & 20.89 & 80.00 \\
\hline
\end{tabular}

The indication $>$ specific only partial production of the infected cells at the indicated highest concentration tested.

than other tested compounds. Also, the order reactivities as $\mathbf{9 a}>\mathbf{1 2}>\mathbf{2}>\mathbf{1 1}$. Based on the resulted data and in compares with results obtained from thiobarbituric acids based HIV-1 integrase inhibitors [3] we can be additional that, the novel fluorinated thiobarbituric acid derivatives in the treatment of HIV infection: 1) nucleoside reverse transcriptase inhibitors; 2) non nucleoside reverse transcriptase inhibitors; 3 ) protease inhibitors and and fusion inhibitors which led to development of new therapies against the virus especially HIV-1 inhibitors.

\subsection{Induction of Apoptosis in Human Leukemia Cells}

Cancer cells differ from the normal cells in a biochemical processes particularly during the control of cell growth and division. Leukemia is one of the major types of cancer affecting significant segment of the population. An important application of small molecule libraries is the preparation of a directed of focused combinatorial library for assay against specific biological target, fluorine substituted thiobarbituric acids were proven to be biologically very potent and selective. In this study, using the fluorine substituted thiobarbituric acid derivatives as anticancer activity via inhibition of cyclin-dependent kinase 1 (CDK2) especially as inhibitors towards human leukemia cells. These evaluations carried out by applied of standard method [25] in biochemical assay with $\mathrm{IC}_{50}$ values comparable to olomoucine as control. The result obtained recorded in (Table 2).

From the results obtained in (Table 2) we showed that: detailed anti-cancer (CDK2 for leukemia cells) activity of the fluorinated thiobarbituric acids are very important used as kinase inhibitor activityin the order $\mathbf{1 2}>\mathbf{7}>$ $\mathbf{2}>\mathbf{3}>\mathbf{4}>$ Olomoucine. Preliminary results indicate that many of compounds exhibit an strong effects in compare with the standard used (Olomoucine). The accepting properties of these fluorothiobarbituric acid derivatives are associated with nucleophilicintramolecular substitutions of fluorine atoms, towards the acceptors with cell-cancer. The prominent role of fluorine substituent effects on bioactivity is mainly due to the effect of fluorination of $\mathrm{C}-\mathrm{H}$ acidity which is predictable and depends on some factors, including the number site of fluorine and the geometry of the conjugate carbanion, which is called bio-conjugation effects. 
Table 2. Results of CDK2 inhibtion evaluation ( $\mathrm{IC}_{50}$ in $\mu \mathrm{mol} /$ Dm3).

\begin{tabular}{cc}
\hline Compound & IC $_{50}$ CDK2 \pm SD $(\mu \mathrm{M})^{*}$ \\
\hline 2 & $4.6 \pm 1.80$ \\
3 & $4.7 \pm 1.00$ \\
4 & $4.8 \pm 1.70$ \\
5 & $6.2 \pm 1.20$ \\
6 & $6.4 \pm 1.97$ \\
7 & $4.5 \pm 1.20$ \\
$9 a$ & $6.8 \pm 1.70$ \\
11 & $4.7 \pm 1.90$ \\
12 & $4 \pm 1.40$ \\
Olomoucine & $5.0 \pm 1.0$ \\
\hline
\end{tabular}

${ }^{*}$ The presented data represent mean values from three independent experiments plus the standard deviation (SD).

\section{Acknowledgements}

I would also like to extend my sincere thanks and appreciations to all technical staff members at National Cancer Institute USA for valuable medical evaluation. Also, I thank for all technical staff member at Chemistry Labs (UV, IR, NMR) spectra.

\section{References}

[1] Srivasta, A.V.K. and Kumar, A. (2004) Synthesi of Some Newer Derivatives of Substituted Quinazolinonyl-2-oxo Thiobarbituric Acids Potent Anticonvulsant Agents. Bioorganic Medicinal Chemistry, 12, 1257-1264. http://dx.doi.org/10.1016/j.bmc.2003.08.035

[2] Novak, I. and Novac, B. (2010) Elictronic Structure and Biological Activity. Chemical Physics Letters, 403, $242-244$. http://dx.doi.org/10.1016/j.cplett.2010.05.062

[3] Rajamaki, S., Innitzer, A., Falciani, C., Tintori, C., Christ, F. and Witvronw, M. (2009) Exploration of Novel Thiobarbituric Acid, Rhodanine, and Thiohydantion-Based HIV-1 Integrase Inhibitors. Bioorganic Medicinal Chemistry Letters, 18, 3615-3618.

[4] Sabir, S.M., Saman, S.M. and Rocha, J.B.T. (2012) Antioxidant Properties of B-Seleno Amines against Lipid Peroxidation in Rat Brain and Liver. Environmental Toxicology and Pharmacology, 34, 446-453. http://dx.doi.org/10.1016/j.etap.2012.06.002

[5] Ma, L., Li, S., Zheng, H., Chen, J., Lin, L., Ye, X., Chen, Z., Xu, Q., Chen, T., Yang, J., Qiu, N., Wang, G., Peng, A.P., Wei, Y. and Chen, L. (2011) Synthesis and Biological Activity of Novel Barbituric and Thiobarbituric Derivatives against Non-Alcoholic Fatty Liver Disease. European Journal of Medicinal Chemistry, 46, 2003-2010. http://dx.doi.org/10.1016/j.ejmech.2011.02.033

[6] Zhang, D., Zhang, J., Li, W., Aimaiti, G., Tuersun, G. and Ye, J. (2011) A Novel Miniaturized Electrophoretic Method for Determining Formaldehyde and Acetaldehyde in Food Using 2-Thiobarbituric Acid Derivatisation. Food Chemistry, 129, 206-212. http://dx.doi.org/10.1016/j.foodchem.2011.04.025

[7] Balas, V.I., Verginadis, I.I., Geromichalos, G.D., Kourkoumelis, K., Male, L., Hursthouse, M.B., Repana, K.H., Yiannaki, E., Charalabopoulos, K., Bakas, T. and Hajikakou, S.K. (2011) Synthesis, Structural and Characterization and Biological Studies of Triphenyltin (IV) Complex with 2-Thiobarbituric Acid. European Journal of Medicinal Chemistry, 46, 2835-2844. http://dx.doi.org/10.1016/j.ejmech.2011.04.005

[8] Makki, M.S.T., Bakhotmah, D.A. and Abdel-Rahman, R.M. (2012) Highly Efficient Synthesis of Novel Fluorine Bearing Quinoline-4-Carboxylic Acid and the Related Compounds as Amylolytic Agents. International Journal of Organic Chemistry, 2, 49-55.

[9] Makki, M.S.T., Abdel-Rahman, R.M., Faidallah, H.M. and Khan, K.A. (2013) Synthesis of Fluorine Substituted Hetercyclic Nitrogen Systems Derived from p-Aminosalicylic Acid as Antimylobacteral Agents. Journal of Chemistry, 
2013, 8 p. http://dx.doi.org/10.1155/2013/819462

[10] Abdel-Rahman, R.M. and Ali, T.A. (2013) Synthesis and Biological Evaluation of Some New Polyfluorinated 4-Thiazolidinone and $\alpha$-Aminophosphonic Acid Derivatives. Monatshefte für Chemie, 144, 1243-1252.

[11] Abu-Elwafa, S.M., Abdel-Rahman, R.M. and El-Gendy, Z. (1990) Spectroscopic Studies of Some Anilide Compounds Derived from Ethyl Benzoyl Acetate. Egyptian Journal of Chemistry, 33, 387-398.

[12] Makki, M.S.T., Bakhotmah, D.A., Abdel-Rahman, R.M. and El-Shahawy, M.S. (2012) Desgining and Synthesis of New Fluorine Substituted Pyrimidine-Thion-5-Carbonitriles and Related Derivatives as Photochemical Probe Agents for Inhibition of Vitiligo Disease. International Journal of Organic Chemistry, 2, 311-320. http://dx.doi.org/10.4236/ijoc.2012.223043

[13] Sead, M., Abdel-Rahman, R.M. and Abdel-Magide, M. (1993) Synthesis of 1,3-Disubstituted-2,3-Dihydro-2-Thioxo4,6(1H,5H)Pyrimidinones and Related Analogs. Indian Journal of Heterocyclic Chemistry, 3, 9-14.

[14] Abdel-Rahman, R.M. and El-Mahdy, K. (2012) Biological Evaluation of Pyrimidopyrimidiones as Multi-Targeted Small Molecule Inhibitors and Resistance Modifying Agents. Heterocycles, 85, 2391-2414. http://dx.doi.org/10.3987/REV-12-745

[15] Chandrappa, S., Kavitha, C.V., Shahabuddin, M.S., Vinaya, K., Anandak, C.S., Ranganatha, S.K., Raghavan, S.C. and Rangappa, K.S. (2009) Synthesis of 2-(5-((5-(4-Chlorophenyl)Furan-2-yl)Methylene)-4-oxo-2-Thioxo Thiazolidin-3yl)Acetic Acid Derivatives and Evaluation of Their Cytotoxicity and Induction of Apoptosis in Human Leukemia Cells. Bioorganic Medicinal Chemistry, 17, 2576-2584. http://dx.doi.org/10.1016/j.bmc.2009.01.016

[16] Abdel-Rhman, R.M. (2001) Role of Uncondensed 1,2,4-Triazine Compounds and Related Heterbicyclic Systems as Therapeutic Agents. Pharmzie, 56, 18-22.

[17] Abdel-Rhman, R.M., Seada, M., fawzy, M. and El-Baz, I. (1994) Synthesis of Some New 1,6-Dihydro-3-Sub-Stituted6-Spiro(9'-Fluorine)-1,2,4-Triazine-5-(4H)Ones as Potential Anti HIV and Anti Cancerdrugs. Pharmazie, 49, 729-733.

[18] Abdel-Rhman, R.M., Seada, M., Fawzy, M. and El-Baz, I. (1993) Synthesis of Some New Thioethers of 1,2,4-Triazine-3-Hydrazones and Assays for Their Anti Cancer and Anti Human Immune Virus Activities. Farmaco, 48, 397406.

[19] DeClarq, E. (2002) New Developments in Anti HIV Chemotherapy. Biochimicaet Biophysica Acta, 1587, $258-275$.

[20] Abdel-Rahman, R.M. (1991) Synthesis and Anti Human Immune Virus Activity of Some New Fluorine Containing Substituted-3-Thioxo-1,2,4-Triazin-5-Ones. Farmaco, 46, 379-389.

[21] El-Gendy, Z., Morsy, J., Allimony, H.A., Ali, W.R. and Abdel-Rahman, R.M. (2001) Synthesis of Heterobicyclic Nitrogen Systems Bearing the 1,2,4-Triazine Moiety as Anti-HIV and Anticancer Drugs, Part III. Pharmzie, 56, 376-383.

[22] Abdel-Rahman, R.M., Morsy, J.M., Hanafy, F. and Amene, H.A. (1999) Synthesis of Heterobicyclic Nitrogen Systems Bearing the 1,2,4-Triazine Moiety as Anti-HIV and Anticancer Drugs, Part I. Pharmzie, 54, 347-351.

[23] Abdel-Rahman, R.M. (1999) Synthesis and Chemistry of Fluorine Containing Bioactive 1,2,4-Triazines-An Overview. Chemistry of Uncondensed 1,2,4-Triazines, Part III. Pharmzie, 54, 791-803.

[24] Weislow, O.S., Kiser, R., Fine, D.L., Bader, J., Shoemaker, R.H. and Boyd, M.R. (1989) New Soluble-Formazan Assay for HIV-1 Cytopathic Effects: Application to High-Flux Screening of Synthetic and Natural Products for AIDSAntiviral Activity. Journal of the National Cancer Institute, 81, 577-586. http://dx.doi.org/10.1093/jnci/81.8.577

[25] Matthews, D.J. and Gerritsen, M.E. (2009) Targeting Protein Kinases for Cancer Therapy. Wiley, Hoboken. 
Scientific Research Publishing (SCIRP) is one of the largest Open Access journal publishers. It is currently publishing more than 200 open access, online, peer-reviewed journals covering a wide range of academic disciplines. SCIRP serves the worldwide academic communities and contributes to the progress and application of science with its publication.

Other selected journals from SCIRP are listed as below. Submit your manuscript to us via either submit@scirp.org or Online Submission Portal.
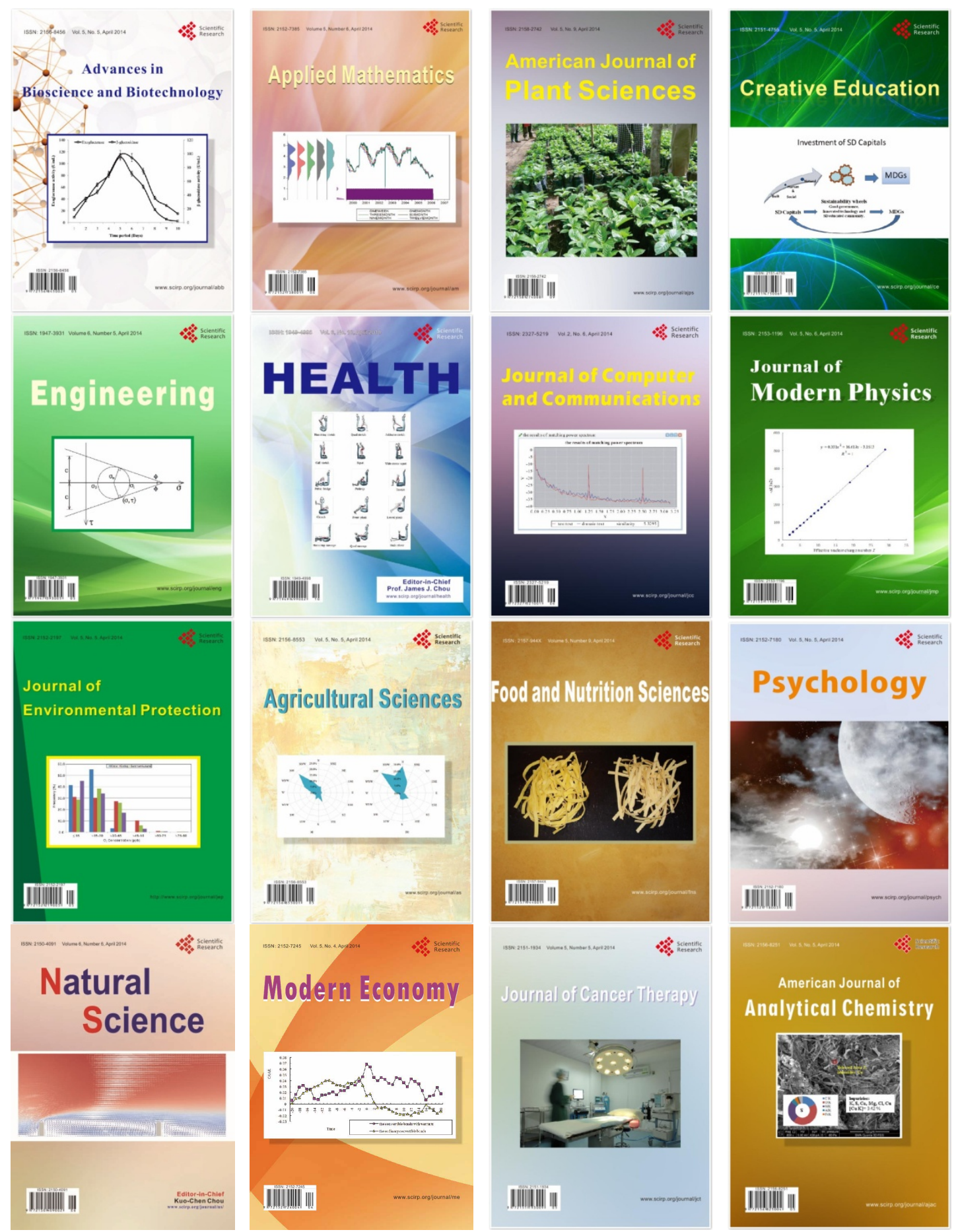